Vladimir Knežević ${ }^{1}$

Aleksandra Penjišević

Union-Nikola Tesla University, Belgrade,

Faculty of management, Sremski Karlovci
SCIENTIFIC REVIEW ARTICLE

DOI: $10.5937 /$ ekonomika2103093K

Received: March, 08. 2021.

Accepted: Jul, 11. 2021.

\title{
THE INFLUENCE OF THE EXCHANGE RATE ON THE TRADE BALANCE OF SERBIA
}

\begin{abstract}
Apstrakt
Subject of this research is contained in its title. We examined the connection and the influence of the foreign exchange rate on the foreign trade balance of Serbia as an independent state in this century, that is, in the period 2007-2017. The aim was to determine whether the theoretical paradigm applies in concrete terms, and that the decline in the value of the domestic currency leads to an improvement in the balance of payments, given the role of price elasticities of import and export demand as well as the level of domestic consumption. The SPSS software package was used for statistical data processing. The observed variables: foreign exchange foreign trade deficit, the exchange rate, the effective nominal exchange rate and the effective real exchange rate are from the point of view of the Scale type. The data were taken from official sources, primarily from the National Bank of Serbia and the Ministry of Finance of Serbia. The obtained results unequivocally confirm that in specific conditions depreciation of the dinar is favorable to the reduction of the deficit of the foreign trade balance. The basic value of this result is that such a policy should continue if the goal is to improve the liquidity of Serbia in international payments. We conclude that the policy of the exchange rate of the dinar in the observed period was properly conducted, and that within the framework of other measures of economic policy, primarily monetary and fiscal, in that sense, gave satisfactory results. In the paper itself, we first defined the basic concepts related to the types and exchange rate regimes. We have added additional conditions for the effectiveness of this policy in order to improve the balance of external trade. By testing the hypotesess we verified the validity of the initial hypotheses of the research. We concluded that the economic policy in this domain in the mentioned period was conducted with due diligence.
\end{abstract}

Keywords: exchange rate, nominal exchange rate, foreign trade balance.

JEL classification: A10,E58,F14.

1 1010brojevi@gmail.com ORICID ID: 0000-0002-0714-175X

2 aleksandra_penjisevic@yahoo.com, ORICID ID: 0000-0002-0898-6818 


\title{
УТИЦАЈ ДЕВИЗНОГ КУРСА НА ТРГОВИНСКИ БИЛАНС СРБИЈЕ
}

\begin{abstract}
Апстракт
Тема овог истраживања је садржана у самом наслову. Испитивали смо повезаност и утицај девизног курса на спољнотрговински биланс Србије као самосталне државе у овом веку, односно у периоду 2007-2019. Циљ је био да утврдимо да ли у конкретним условима важси теоретска парадигма да обарање вредности домаће валуте води побољшању платног биланса, обзиром да ту имају улогу и ценовне еластичности увозне и извозне тражне, као и ниво домаће потрошње. За статистичку обраду података коришћен је програмски пакет SPSS. Посматране променьиве: дефицит спољне трговине Србије и девизникурс, су са становишта мерења типа Scale. Подаци су узимани из званичних извора, пре свега од Народне банке Србије и Министарства финансија Србије. Добијени резултати недвосмислено потврђују да у конкретним условима депресијација динара погодује смањењу дефииита спољнотрговинског биланса. Основна вредност овог резултата је да овакву политику треба наставити уколико је ичиљ побољшање ликвидности Србије у међународним плаћањима. Закључујемо да је политика курса динара у посматраном периоду вођена правилно, и да је у склопу других мера економске политике, пре свега монетарне и фискалне, дала у наведеном смислу задовољавајуће резултате. У самом раду смо прво дефинисали основне појмове везане за врсте и режиме девизних курсева. Навели смо и додатне услове за ефикасност ове политике у изиьу поправљања биланса спољне трговине. Поступком тестирања хипотеза смо проверили валидност полазне хипотезе истраживања. Закључили смо да је економска политика у овом домену у наведеном периоду вођена сврсисходно.
\end{abstract}

Кључне речи: девизни курс, номинални девизни курс, сполнотрговински биланс.

\section{Introduction}

In this century, Serbia is characterized by a permanent deficit in foreign trade, which is also the main cause of the chronic deficit of payments balance. This, on the other hand, in practice affects high external indebtedness. Therefore, it could be said that one of the basic current tasks of economic policy of every Serbian government the elimination, or at least mitigation, the problem of high deficit of the trade balance with foreign countries.

It is only by itself understood that the key would be to reduce imports and increase exports, seen in value terms. Current trends in Serbian politics definitely do not make administrative measures the first choice for action in this direction. Foreign policy repercussions, such as the drive for EU membership (hereinafter EU), and the World Trade Organization (WTO) policy, which opposes non-tariff restrictions on imports, direct Serbia to reduce its import demand primarily through restrictions on the overall domestic demand. These measures are already in use, especially since the half of the second decade of this century. Referred to so far primarily to budgetary restrictions, especially when it comes to pensions and public sector wages and employment of budget 
users. Also, inflation was kept under successful control by keeping a restrictive monetary policy.

On this side, the government, elected in 2017, did what it could from the aspect of its jurisdiction over the conduct of economic policy in this short term. It is also the National Bank of Serbia (hereinafter NBS), pursued a consistent, fundamentally monetarist, targeted inflation policy. At the moment, we should be interested in another aspect of the foreign trade deficit, which is the possibility of increasing the competitiveness of Serbian exports. Taking into account the already explained conditions advocated by the EU and WTO, as well as budgetary restrictions, it seems that the only remaining short-term policy is the exchange rate policy. In theory and practice, the prevailing attitude is that the weakening of the domestic currency, in general, positively affects the foreign trade balance.

When we take into account all the exposed items, we estimate that it is an interesting question of whether, how and to what extent, exchange rate manipulation can correct the trade balance of a country. More precisely, the aim of our research is to determine the link between the movement of the foreign exchange rate of the dinar and the foreign trade balance of independent Serbia in this century, in the period from 2007 to 2019.

\section{General issues of exchange rate and trade balance}

At the beginning of the presentation, methodologically, it would be most useful first to define the meaning of the terms to be dealt with in our analytic, in order to avoid any possible ambiguities and misunderstandings that are possible due to insufficiently precise use of terms. Let's first see what we mean by the exchange rate. In simplest terms, the exchange rate is the price at which one currency is exchanged (bought and sold) for the other currency. If we wanted to be scientifically correct and maximum precise, this definition means the nominal exchange rate, in the following presentation, we will use even terms such as real viewing exchange rate, effective, effective nominal and effective real exchange rate. So, we announce that in this work, when we say only the exchange rate, we will only think about the nominal, what we encounter normally in banks and exchange offices, everyday life and regular business.

If we aspire to the maximum deflection of any possible ambiguity in terminology, by the term exchange rate, if we do not use it with some additional heading, will mean in his speech already mentioned the nominal exchange rate and with the implementation of direct notation.

In the previous presentation we have already mentioned the adjustment of the nominal exchange rate. Because the real and effective exchange rate are calculated categories, which essentially represent adjustments to the nominal exchange rate, results that a country can only make adjustments to the nominal exchange rate. Namely, the policy of the foreign exchange rate of any country is in fact reduced to the adjustment, i.e. change, of the nominal exchange rate of the national currency. How will these changes affect the real effective exchange rate, it depends on inflation and structures of international economic relations of a country and its main partners in the world economy.

As the exchange rate policy is implemented in practice, this is explained by different models, i.e., exchange rate regimes. According to the classification of the International Monetary Fund (hereinafter: the IMF), there are the following types of exchange rate regimes: 
1. Exchange rate arrangements without special means of payment;

2. Arrangements of the Currency Board;

3. Other conventional fixed PEG arrangements;

4. The fixed exchange rate is within the horizontal range;

5. Crawling exchange rate;

6. Exchange rate inside the crawling frame;

7. Managed floating exchange rate without a predetermined way;

8. Independent fluctuating. (Josifidis, Alegret \& Beker, 2009)

The seventh model implies that the monetary authority is trying to influence the course without a predetermined target exchange rate. Indicators for this course management may be different, which are usually the balance of payments, foreign exchange reserves or market disturbances. Intervention during course management can be direct and indirect. This exchange rate regime does not operate according to the automatic principle, it is a modality of discretionary economic policy.

Since our research is dealing with Serbian economy, the fluctuating exchange rate model (model No. 7), which is applied throughout the period to which our research relates, is important to us here. (Marčetić, 2017) This seems to be the optimal choice, since it is applied by many transitional economies. (Jovović, 2011) The National Bank of Serbia (hereinafter referred to as the NBS) intervenes in its discretion in the circumstances when it assesses that market forces in the foreign exchange market move the dinar exchange rate from what it considers acceptable, taking into account the balance of payments situation and the difference between domestic investment and the one in the markets important for the Serbian economy. So, as we have already said, the module is most applicable, which most resembles the seventh variant of the IMF classification.

In practice, the system works by determining daily middle exchange rate of the euro (since 2011 and US dollars) at the interbank meeting. The average exchange rate is the average weighted price achieved on that interbank foreign exchange trade. According to its estimation, the NBS is involved in trade in the purchase or sale of foreign exchange to influence the exchange rate.

And what is the significance of the change in the exchange rate? The exchange rate policy has multiple significance for every economy and in every situation. For less developed countries, as well as for transition economies, the exchange rate has the most impact on the five aspects that we will list. Firstly, in the context of substantially the price level in the domestic market, the exchange rate is an important resource allocation factor. Secondly, the economic development of these countries, the exchange rate, in correlation with other measures of economic policy, can also accelerate from the aspect of industrialization and productivity growth through foreign trade. In market-oriented developing countries, as well as in transition economies, the exchange rate significantly affects the stability of the financial market. Fourth, in conditions of significant import dependence, an adequate exchange rate policy can be an important anti-inflationary tool. In the end, but from the aspect of our research and, most importantly, the exchange rate has a major impact on the balance of payments, as it depends on the relative relation between domestic and foreign prices of goods and services.

Therefore, the basic problem of the Serbian economy in the sphere of international economic relations is the current account deficit. More precisely, the long-term problem is 
a chronic deficit in exchange of goods and services abroad, and foreign trade balance. The significance of this statement is especially difficult for the tendency of the long-term decline in foreign exchange in flows based on remittances of workers from abroad. It should be noted that the trade deficit is a regular occurrence in countries like Serbia, in a middle and lower level of development, which is expressed in the import dependence of the economy due to the high demand for investment periods rhyme, raw materials and technology that cannot be met from domestic sources. Regardless of the fact that there is always a factor in the import of consumer goods and services, the fact is that the deficit cannot be solved completely by suppressing domestic consumption. The only sustainable long-term solution is in the growth of the creation of goods and services for the foreign market and the competitiveness of such exports.

Shortly, there is a necessity for the growth of exports, above all, with reductions in the import, which would not be at the expense of the development of economy. So it would be equalized just to enter the balance as the key of equalized balance of payments as a whole. This is, of course, an indicator of the current economic policy, where an exchange rate policy can play an important role. Thus, we should see how the exchange rate policy affects the trade balance of a country.

With all the basics postulates in mind, the way of thinking could be very simple. Thus, the weakening of national currency (exchange rate growth), regardless of whether it is a devaluation (fixed mode) or depreciation (fluctuating mode), it must be beneficial to eliminate the trade deficit. How this mechanism works? Simply, the weakening of the currency stimulates exports, and destimulates imports.

The previously stated logic of thinking is traditionally very rooted. It is very common in everyday reflections on this issue, in numerous media, politics, and with several economists. However, there are numerous theories in this field that argue that things are not as simple as it seems at first glance, and as we have shown it in our simplified model. Therefore, in the next presentation, we will present in short terms the basic idea of the most famous theoretical considerations of this problem.

At the center of all theories dealing with the influence of the exchange rate on the correction or balancing of the negative foreign trade balance is the idea that this is not enough only for the manipulation of the exchange rate, i.e., the collapse of the value of the domestic currency. In order to achieve the potential positive results according to the simple model logic described above, it is necessary to fulfill some additional conditions. This is completely understandable when we know how complicated the macroeconomic processes are, and especially those related to the foreign trade balance.

Our presentation in this section will begin with the introduction of Marshall-Lenart's theorem. This theorem can be summarized in a single sentence shortly. It says that the weakening of the domestic currency in terms of the growth of the real exchange rate will have a positive effect on leadership in the trade balance if the sum of the price elasticity of foreign demand for domestic goods and domestic demand for foreign goods is greater than one. (Marčetić, 2017) This certainly depends on the existing economic structures, both in the country and abroad, given that these elasticities are different for each branch. (Popović, 2009)

It should be noted here that, in case of satisfying elasticity conditions, two phenomena should be taken into account. Firstly, a positive effect on the trade balance will be seen in the longer term, which is not shorter than a year, as it takes some time to adjust production and income. The other thing is, the almost regular occurrence of the J curve effect, that is, 
the improvement of the trade balance due to the drop in the value of the domestic currency, comes only after the initial deterioration. The main reason for this is that in the first period after the change in the foreign exchange rate, foreign trade contracts, which are concluded up to the previous period, are realized as a rule. The size of the effect depends on the structure of the contracts according to the currencies in which they are made. (Đelić, 1993)

In addition to this basic idea of the theory of elasticity that is briefly exposed, we consider another important direction of thinking within this issue important for mentioning in this place. This is the so-called absorption model, which essentially deepens the analysis of the impact of depreciation (and devaluation) on the foreign trade balance. Namely, the change in the exchange rate in this direction will affect the balance in line with the stated elasticities, but these processes are also related to adjusting production, income and demand in the domestic economy, which again also affects the foreign trade balance. Thus, this theory, by complicating the model, takes us closer to real economic developments by considering new variables. There are also other factors involved, such as the propensity of import and savings are added.

In this model, it is basically argued that for positive changes in the foreign trade balance due to depreciation, it is necessary that there is domestic real savings, that is, that real expenditures are lower than real incomes. The logic is simply that domestic demand does not "eat" surpluses for exports. So, the economy is a complex model, and must take into account the changes in supply and demand in the domestic market because of this greatly affect the final aim of the trade balance, not just the price elasticity of demand for imports om and export.

Therefore, the basic idea of the model is that in addition to depreciation, if the foreign trade balance is desired, the domestic consumption should be limited by the measures of monetary and fiscal policy. Everything is based on the famous Keynesian idea, that the surplus of the trade balance is in fact a surplus of total domestic production.

The basic equation shows that domestic production $(\mathrm{Y})$ represents exactly the sum of the absorption (A) and the trade balance $(\mathrm{X}$ - M), i.e. net exports, where $\mathrm{X}$ represents export, and $\mathrm{M}$ imports. It follows:

$$
\mathrm{Y}-\mathrm{A}=\mathrm{X}-\mathrm{M}
$$

Therefore, the excess domestic production above total domestic consumption (absorption) is the only possible source of positive difference between exports and imports. If domestic consumption is higher than domestic production, it will have a trade balance deficit. This means that this surplus of production above the absorption is a necessary condition for improving the foreign trade balance even in the conditions when there is depreciation to domestic currency, and the sum of the price elasticities of domestic and foreign demand for import goods and services meets the previously explained conditions.

We have drawn two of the most influential ones, and for us, really the two most important theories to be kept in mind when pursuing economic policy in this field. Of course, economic reality is so complex that in any theory and model it is impossible to include all relevant factors, make their quantification, and precisely define mutual relations. However, we have so far been said to be a completely sufficient basis for further discussion on the link between the exchange rate and the foreign trade balance.

After all that we have already said, we can now begin our discussion of the link between the foreign exchange rate and the foreign trade balance of Serbia in the period from 2007 until 2019. Our starting hypothesis will be that the depreciation of the 
exchange rate of the dinar against the euro is not firmly related to the reduction of the deficit of the foreign trade balance.

\section{Empirical study of exchange rate movements and foreign trade balance}

In order to study the mentioned macroeconomic issues, which relate to foreign exchange rate and foreign policy, it is best to use official published data from authoritative sources such as specialized international organizations as well as official national authorities. So we will rely on the data contained in official publications of the World Bank (WB), Eurostat, NBS, the Ministry of Finance of the Republic of Serbia and the Republic Institute for Statistics.

Once again, we will remind that the subject of research from the mentioned aspects is the economy of modern Serbia. Here we have in mind Serbia, which in the 21 st century became a state of autonomy in mid-2006. That is why we selected the period between 2007 and 2019 for the period of study. We believe that more than one decade is a sufficient period for some reliable conclusions regarding the subject of our research to be carried out.

Therefore, we will try to perceive the quantitative and qualitative aspect of the relationship between the movement of the foreign exchange rate of the Serbian national currency and the balance of its foreign trade. The first one will deal with the exchange rate towards the euro that "covers" in the mentioned period for the largest part of Serbia's foreign trade. In the following, we will not discuss the modalities of the effective exchange rate, taking into account other relevant currencies, which are apart from the euro and the dollar, as well as the Swiss franc, the British pound, the Chinese and the Japanese currency. This is because a broader analysis would go far beyond the format of this article.

We will methodology expose our report by starting from the foreign trade balance, and then we will analyze the movement of the exchange rate and investigate the relationship between it and the balance.

For a statistical data processing we will use a software package SPSS. The observed variables foreign exchange foreign trade deficit, the exchange rate, the effective nominal exchange rate and the effective real exchange rate are from the point of view of the Scale type.

We already know that the economy is continuously following the chronic deficit of the foreign trade balance. The following figure gives an overview of the deficit in the exchange of goods and services in the period we are studying, expressed in millions of euros.

Table 1: Deficit of foreign trade of Serbia (goods and services) in mil. EUR

\begin{tabular}{|c|c|c|c|}
\hline YEAR & DEFICIT & YEAR & DEFICIT \\
\hline 2007 & $-7,376.2$ & 2014 & $-4,028.7$ \\
\hline 2008 & $-8,854.2$ & 2015 & $-4,047.9$ \\
\hline 2009 & $-5,365.7$ & 2016 & $-3,635.8$ \\
\hline 2010 & $-5,030.1$ & 2017 & $-4,345.2$ \\
\hline 2011 & $-5,808.6$ & 2018 & $-5,636.6$ \\
\hline 2012 & $-5,973.9$ & 2019 & $-6,341.6$ \\
\hline 2013 & $-4,472.5$ & & \\
\hline
\end{tabular}

Source: Ministry of Finance, from the site www.mfin.gov.rs (accessed on April 7, 2020) 
By observing the variable Foreign Trade Deficit of Serbia in the period from 2007 to 2019, we can notice that:

1. the average deficit of foreign trade amounts to EUR 5381.28 million ;

$95 \%$ confidence interval is $(4417,38-6345,19)$ which means that with a probability of $95 \%$ we claim that the deficit is moving in this interval;

the data in the series are not homogeneous since the coefficient of variation

$$
\mathrm{v}=\frac{\mathrm{s}}{\overline{\mathrm{x}}} \times 100=\frac{1517,08}{5381,28} \times 100=28,19 \%
$$

smaller than $30 \%$.

Figure 1. Deficit of Serbian trade in the period 2007-2019

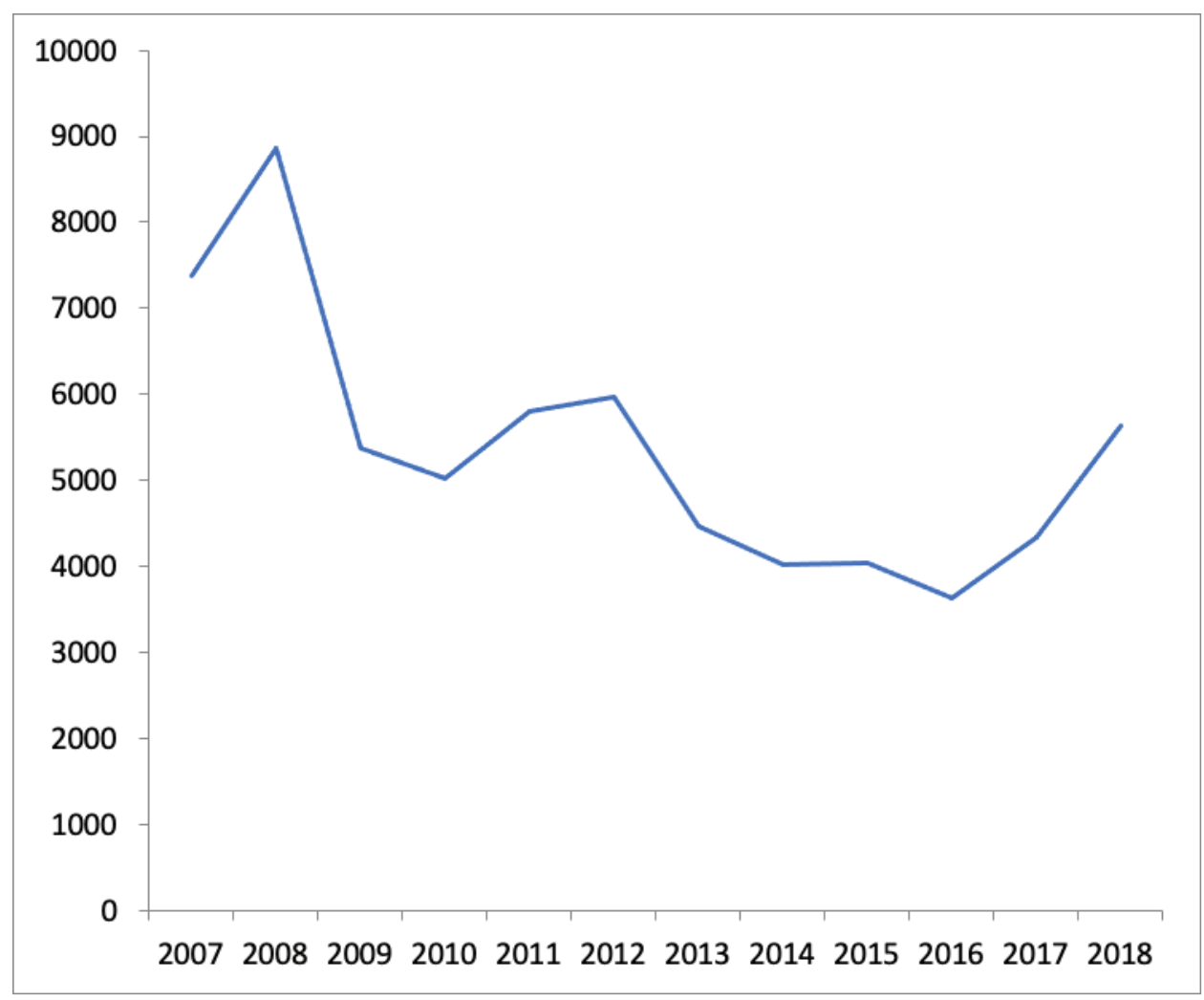

Source: Authors, according to Ministry of Finance data, available at www.mfin.gov.rs (accessed

7.4.2020.) 
Figure 2. Box-plot diagram Foreign trade deficit of Serbia in the period 2007-2019.

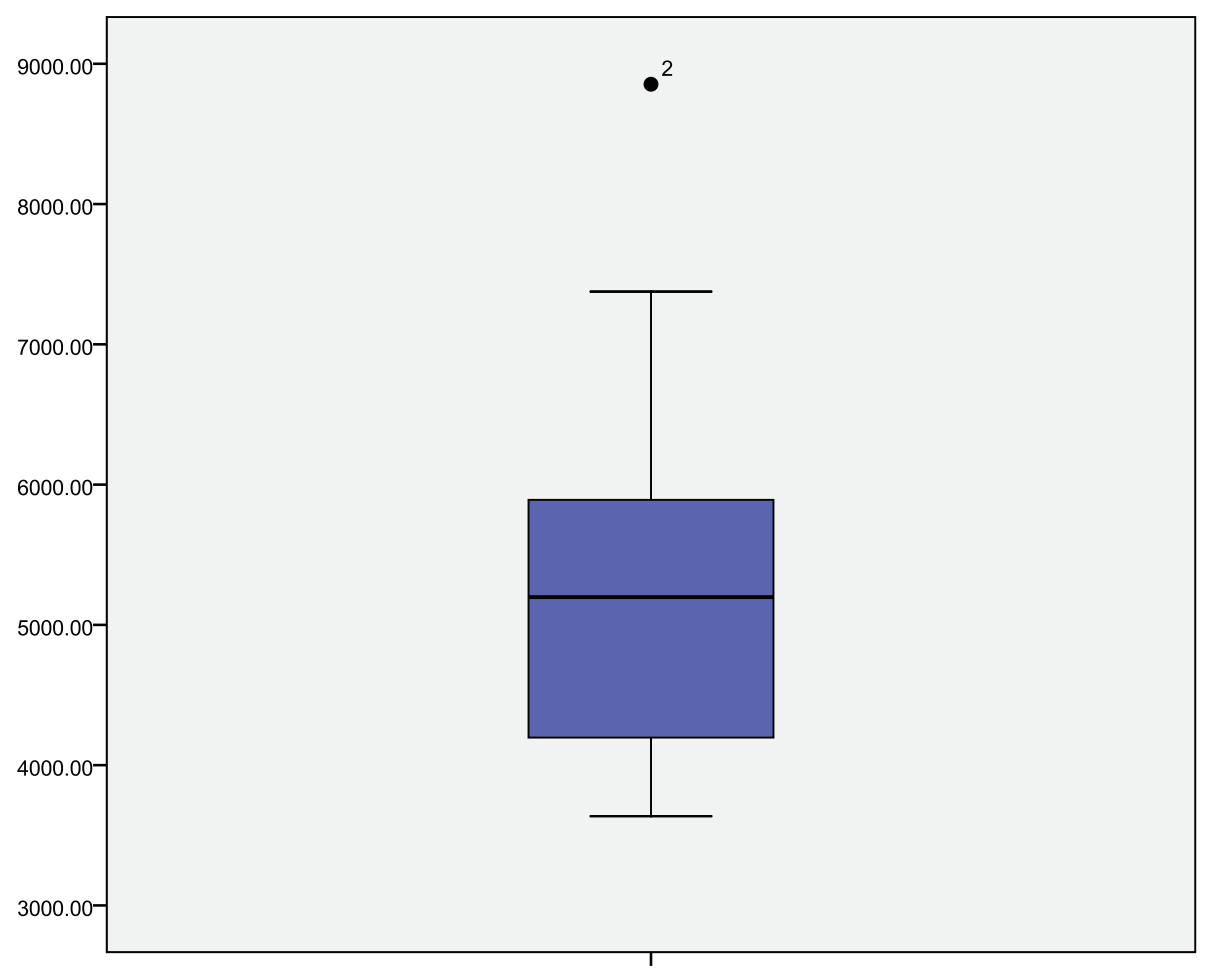

Source: Authors, according to Ministry of Finance data, available at www.mfin.gov.rs (accessed 7.4.2020.)

On the box-plot chart (Figure 2) Foreign trade deficit for the period 2007-2019. year, we can see one outlier (an exclusive point, an observation that is different from the others) data and the value of the foreign trade deficit for 2008 .

Now, let's take a look at how the nominal exchange rate of the dinar and the euro in the same period.

Table 2: Exchange rate RSD for EUR (end of period)

\begin{tabular}{|c|c|c|c|}
\hline YEAR & EXCHANGE RATE & YEAR & EXCHANGE RATE \\
\hline 2007 & 79.24 & 2014 & 120.96 \\
\hline 2008 & 88.60 & 2015 & 121.63 \\
\hline 2009 & 95.89 & 2016 & 123.47 \\
\hline 2010 & 105.50 & 2017 & 118.47 \\
\hline 2011 & 104.64 & 2018 & 118.19 \\
\hline 2012 & 113.72 & 2019 & 117.59 \\
\hline 2013 & 114.64 & & \\
\hline
\end{tabular}




\section{Discussion of work results}

At first, it should be noted that this study we access just because we have the impression that in our professional public these works are not sufficiently represented. Namely, in the past twelve years of Serbian statehood, in our opinion, this problem was not addressed enough by economists. Occasionally and partially there were critical texts about some aspects of this issue. The profession is quite justified, for example, against the fixed exchange rate at the beginning of the transition. However, the impression is that not enough attention paid to the influence of the foreign exchange rate on the trade balance of Serbia as an independent state in the first decade of its existence in the 21st century.

In our wider, but also in professional public, there was certainly a reaction to certain exchange rate fluctuations. It was an assessment that at certain moments the current course corresponds to the "import lobby", or that the policy itself is not enough to reduce the trade deficit of Serbia. Of course, these issues, and that we pointed out in the paper, are very complex. Therefore, we have decided to specifically quantify only one aspect, and to try to give a clear answer to at least one question from this complex set of macroeconomic problems. How and in which extent the course influenced the foreign trade balance of Serbia in the mentioned period. We finally offered an unambiguous answer to that.

In this we see the contribution of this paper. We picked out a precisely defined question and gave it a clear answer. We consider such an approach important for all macroeconomic issues of Serbia in the conditions of its new independence. It should come out of endless theoretical discussions and outwits. It is necessary to solve one and the same question in a clear and argumented way and redirect to the next ones to meet. Maintenance is done to serve the dilemma. Which course to choose? What course policy do you take? It cannot always be at the beginning. Is there any progress in transition?

We made the effort to contribute to this work by checking the theory in concrete practice. We believe that the previous analysis showed that in the conditions of the Serbian economy in the period 2007-2017, the course would be a very important element of foreign trade policy. Its influence on the foreign trade balance of Serbia in the mentioned period is undisputed and fully in line with the ruling theory. In other words, we think that topic which is being studied and the period, the practice fully confirmed the theory.

The practical implication for foreign policy makers of Serbia would be to continue with the practice of depreciation of the nominal dinar exchange rate against the euro and that any other behavior would lead to deterioration of the foreign trade balance.

\section{Conclusion}

In this paper we were shortly dealing with what is indicated in the title, so the impact of the exchange rate on the balance of payments of Serbia. We have considered the basic categories of exchange rates and foreign exchange regimes, as well as the most important relations between them. We also highlighted the main elements of the balance of payments. We also looked at the main theories explaining the modalities for alleviating the problem of the deficit of the foreign trade balance. Research, which could possibly be called a case study of the independent state of Serbia in this domain during the period 2007-2019, focused on the verification of the link between the exchange rate and the foreign trade balance. Having 
explained the indisputably great importance of the nominal dinar exchange rate against the euro, we have just placed the emphasis here. The purpose was to determine and quantify this relationship on a concrete case. We wanted to check the theory and practice, to end the unfruitful discussions and to evaluate the economic policy that is being conducted.

As we have already pointed out, focus of the research was at the exchange rate which is the most important for Serbia. First, the euro is unmatched most important currency for foreign trade of Serbia, and secondly, the nominal exchange rate is the only domain of foreign exchange policy that has a great influence on the foreign trade balance. In concrete case, the connection between theory and practice is confirmed. Namely, the diminution of the value of the dinar (the growth of the euro exchange rate against the dinar) is very much in line with the reduction of the deficit of Serbia's foreign trade. At the same time, it does not corroborate the initial hypothesis that the depreciation of the exchange rate of the dinar against the euro is not in tandem with the reduction of the deficit of the foreign trade balance. In the investigated decade, in the case of Serbia, it was undoubtedly quantified that the depreciation of the exchange rate of the dinar against the euro was very firmly related to the reduction of the deficit of the external trade balance.

This research has unequivocally and surely resulted in the claim that the movement of the nominal exchange rate between the euro (direct invoicing) is affecting the reduction of Serbia's foreign trade deficit (2007-2017), which fully corresponds to the prevailing theory of foreign exchange rates and foreign trade. Certainly, the course of this exchange rate was also influenced by the significant price elasticity of imports (and exports) of Serbia and its main foreign trade partners. If it was not there, or it is insufficient, the effect of the exchange rate would be minimal. Likewise, the correction of the external trade balance through both values of the domestic currency was facilitated by the restriction of domestic consumption by keeping inflation under control and by reducing the budget deficit. [9] However, all this does not change anything on the conclusion nor undermines the result of the research. The balance would not be corrected without such an exchange rate policy. This is supported by a slight rise in the deficit in 2017, which also corresponds to a slight increase in the value of the dinar.

With this work we wanted to show three things. Methodologically we had the intention to promote the approach that it is most appropriate to conduct macroeconomic analysis of the Serbian economy starting in 2017 , because it is only to the first years of independence the country after many decades. This is simply the case, although we often encounter an approach where the Serbian economy is analyzed for a much longer period than the last decade. In our opinion, it is justified in the context of a historical approach on which occasion the emphasis would be on the position of Serbia within several states in which it was composed after the First World War. For current economic analyzes, in our opinion, it was sensible to act only as we did on this occasion.

We also consider the choice of the topic as a certain contribution because we consider that the papers dealing with the policy of the foreign exchange rate of Serbia in the mentioned period are missing. As if this is a little important topic that does not deserve the attention of economists, and as if everything is clear in itself. The fact is that, in the last decade, it has the least problems in terms of the exchange rate and foreign trade balance, but we consider it to be shown, proven and confirmed decisively.

Thirdly, the fact is that the phenomena described in this paper on the line of predominance, could be said to be a "classical" economic approach. Such an approach, where, in this context, the correction of the foreign trade balance is considered to be a useful 
use of the fluctuating exchange regime, the fall in the value of the domestic currency, inflation control and the balancing of the budget deficit is, at the same time, the general approach of the IMF. In this period, this organization has had a considerable influence on the conduct of macroeconomic policy in Serbia. We would like to state once again that such an approach obviously gives results in this area. Namely, for this period, governments mainly criticize the work of the expert public on the direction of the IMF because of the fact that this does not lead to higher rates of economic growth. However, it should be kept in mind that this organization primarily deals with the problems of external liquidity of its members, and that it is not a development agency. In this sense, this policy seems to be the best option. Here, we dealt with exchange rate and foreign trade deficit, and economic development is another, more complex topic that still requires more serious analysis in the coming period.

\section{References}

Alain, M., Jean-Michel. (Eds.). (2007). Democrasy, freedom and Coercion, Cheltenham, UK: Edward Elgar Publishing Limited

Begg, D., Fisher, S., Dornbusch, R. (2010) Ekonomija, Datastatus, Beograd

Đelić, D. (1993). Devalvacija i spoljnotrgovinski bilans, Univerzitet u BeograduEkonomski fakultet, Beograd

Ellison, D. (2008). Competitiveness Strategies, Resource Struggles, and National Interest in the New Europe, The Center for Russian and East European Studies, a program of the University Center for International Sudies, University of Pitsburgh

Eurostat (2017) Key figures in Europe 2016 edition, Luxemburg Publication Office of the European Union

Hall, A., Midgley, J., (2004) Social Policy for Development, SAGE Publications, Thousand Oaks, London, New Delhi. Hanić, H., Šojić, M., (2008), Finansijska statistika, Beogradska bankarska akademija, Beograd

Hanić, H., Šojić, M., (2008), Finansijska statistika, Beogradska bankarska akademija, Beograd

Josifidis, K., Allegret, J., Beker, E. (2009):Exchange Rate Regimes in Emerging and Transition Economies, University of Novi Sad, Faculty of Economics Subotica

Jovović, D., (2011) Dinar i devizni kurs, Prometej, Beograd

Knežević,V., Ivković,D., Penjišević., S. (2017): The economic importance of reducing budget deficit - the case of Serbia, Proceedings of the International Conference "Composite Materials, Ecology, Information Technology,Economics and Law" ISBN978-5-905364-09-9. pp 507-519

Knežević,V., Ivković,D., Vujičić, S. (2013): Competitiveness and Development of National Economy, Economic Analisys, No 1-2/2014, str:111-127

Kornai, J., (2000) Ten years after the road to a free economy, The World Bank, Annual Bank Conference on Development Economics, ABCDE, Aprill 18-20.

Mann, P., (2010), Uvod u statistiku, Za izdanje na srpskom jeziku Centar za izdavačku delatnost Ekonomskog fakulteta u Beogradu, Beograd 
Ivanović, M., Penjišević, A. (2019), Mudrost malih koraka - Upravljenje malim biznisima, Eurografika, Zvornik, ISBN 978-99976-40-06-2, www.miodragivanvic.com

Marčetić, M., (2017) Analiza eksterne neravnoteže Srbije, Doktorska disertacija, Univerzitet Union, Beogradska bankarska akademija, Fakultet za bankarstvo, osiguranje i finansije, Beograd.

Marić, N., (2009), Statistika kompjuterski pristup, DATA STATUS, Beograd

Michelle, C., Nieves Perez, S. (Eds.). (2010). European Union politics-third edition, New York: Oxford university press.

Milenković, N., (2012): Devizni kurs kao element ekonomske politike-iskustva zemalja Istočne Azije, Ekonomski horizonti, 14 (3), str. 139-149

Ministarstvo finansija Republike Srbije (2018) Bilten javnih finansija broj 167, Beograd

Popović, D., (2009) Šta je to realni devizni kurs?, Prizma, Beograd. str. 29-36.

Republički zavod za statistiku Srbije (2018) Statistički godišnjak Republike Srbije 2018, Beograd

Schwab, K. (Eds.). (2017). The global competitiveness report 2017-2018 Geneva: World economic forum, http://www.weforum.org/reports

Todorović, M., Marković, M. (2016) Uticaj depresijacije nacionalne valute na trgovinski bilans Republike Srbije, Teme, g. XL., br. 1, januar-mart 2016, str. 139-154.

United Nations Development Programme (2016) Human Development Report 2016, Human Development for Evryone, New York

Vanke, J. (2010). Europeanism and European Union, Academica Press, Palo Alto

\section{Internet sources}

http://data.worldbank.org/indicator/NY.GDP.MKTP.CD

http://www.mfin.gov.rs

http://www.weforum.org/reports 
